\title{
Performance evaluation of cocoa marketing in Osun State, Nigeria
}

\section{Joseph Olumide Oseni ${ }^{1}$; Adewale Isaac Olutumise ${ }^{2}$; Boluwaji Olusola Olutumise ${ }^{1,3}$}

\author{
${ }^{1}$ Department of Agricultural and Resource Economics, Federal University of \\ Technology, Ondo State, Nigeria. \\ ${ }^{2}$ Department of Agricultural Economics and Extension, Adekunle Ajasin University, \\ Ondo State, Nigeria. \\ ${ }^{3}$ Procurement Department, Engineering Materials Development Institute, Ondo State, \\ Nigeria.
}

e-mail correspondence: adewale.olutumise@aaua.edu.ng

\begin{abstract}
This paper appraised cocoa marketing performance in Osun State, Nigeria. The study specifically examined the costs and returns associated with cocoa marketing, and determined factors affecting cocoa marketing performance in the area. Primary data were used and collected through a well structured questionnaire and focus group discussion session. A multistage sampling procedure was employed to randomly select 120 respondents for the study. The analytical tools used were: descriptive statistics, budgetary analysis and Seeming Unrelated Regression Equation (SURE).The results of costs and returns using budgetary analysis showed that cocoa marketing is a profitable enterprise with a Return on Investment (ROI) of 1.36 which implies that cocoa marketer will realize 36Kobo on each naira expended. Again, percentage profit of over $35 \%$ further confirmed that cocoa marketing is a highly profitable venture in the study area. The SURE results showed that age of the cocoa marketers, marital status, household size, years of education, years of marketing experience, marketer institution group, depreciation cost on fixed inputs, number of stores, cost of labour, cost of transportation, season of sales, cocoa bean quality and incidence of theft were statistically significant factors affecting performance of cocoa marketing in the study area.
\end{abstract}

Keywords: Cocoa beans, marketing, SURE, profitability, Nigeria

JEL classification: M31, Q13

\section{INTRODUCTION}

Cocoa (Theobroma cacao) is one of the promising enterprises that could have the potential opportunities for economic growth and development in Nigeria. It is a key product among the less than 5\% exportable products from Nigeria that is officially available in the world market (Nigerian Export Promotion Council [NEPC], 2001).

Based on its numerous benefits, it is one of the options for diversification of the economy from predominantly mono-cultural, which largely depends on crude oil for its foreign exchange earnings (Owofemi, 2008). Again, the value chains in cocoa which ranges from production through marketing to processing can be a good strategy to revitalize Nigeria's economy.

Due to recurrent economic recession and meltdown always experience by 
Nigeria's government over the years, the Federal and State Governments in the past have made it a matter of policy to diversify the present over dependence of the country's economy on oil, by focusing on tree crops such as: cocoa and food crop production which is a reflection of the setup of the presidential initiative on the production of these crops (Folayan, Oguntade and Ogundari, 2007). As recorded by Nwachukwu, Ezeh and Emerole (2012), the production capacity of cocoa in Nigeria has reached about 385,000 metric tonnes per annum, an increase of 215,000 metric tonnes from year 2000 production level.

According to International Cocoa Organisation (ICCO) (2016), this increase in production places Nigeria as the fourth largest cocoa producer in the world in the 2013/2014 season based on its production output of 230,000 metric tonnes after Côte d'Ivoire, Ghana and Indonesia. Nigeria further falls from four to seven in the 2015/2016 season with the production output of 190,000 metric tones. However, this is in sharp contrast to 1964, when Nigeria was the second largest cocoa producer in the world. This implies that Nigeria can still compete favourably with other leading world cocoa producers in supplying cocoa to the world market.

As reported by Oladosu and Yekini (2008), in the early forties, the cocoa industries contributed on the average $21.5 \%$ of all foreign exchange earned by Nigeria in the world market. Taphee, Musa and Vosanka (2015) also reported that 154,275 tonnes of cocoa were exported in 1993 at the rate of $\$ 926$ per tonne; thereby contributing a total amount of 71.4297 million naira to the Nigerian economy. Annual production stood at 240,000 tonnes in 2009; about $98 \%$ of the cocoa produced were exported. According to the Nigerian Export Promotion Council (NEPC), in 2014 alone, Nigeria recorded the highest export of cocoa and its products valued at $\$ 131.2$ billion.

In terms of employment generation, a sizeable number of people either directly or indirectly have been gainfully employed in the cocoa subsector. In addition, it is an important source of raw materials for the industries as well as a source of revenue to the governments of the various cocoa producing states in the Nigeria. Again, the thorough knowledge and understanding of the distribution chain, market trends and developments, and the special characteristics of trading and the exchanges are very germane for anyone to succeed in cocoa business (Ogunleye and Oladeji, 2007).

In spite of the significance of cocoa marketing in terms of employment opportunities, income generation and foreign exchange earnings cum contribution to Nigeria's Gross Domestic Product (GDP), it has been noted by Folayan et al. (2006) and Fadipe et al. (2012) that cocoa production in Nigeria has witnessed a downward trend after 1971 season. It was therefore observed that its export declined to 216,000 metric tonnes in 1976 and 150,000 metric tonnes in 1986. As a result of this decline, the country's market share reduced to about $6 \%$ and to fifth largest producer to date due to a combination of labour shortages and low producer prices.

In recent time, the Federal Government's concern at diversifying the nation's export base has placed cocoa in the centre-stage as the most important export tree crop. However, with the continued decline in the fortunes of the sub-sector an empirical insight into marketing performance and factors affecting level of returns in the sector would be of immense importance to government, policy makers and cocoa marketers. The general objective of this study is to appraise performance of cocoa marketing in Osun State, Nigeria. The specific objectives are to estimate the costs and returns associated with cocoa marketing; determining factors affecting cocoa marketing performance; and identify main constraints to cocoa marketing in the study area. 


\section{RESEARCH METHODOLOGY}

The study was carried out in Osun State, Nigeria. According to the National Population Census conducted in 2006, Osun State has a population of 3,423,535 people (NPC, 2006). The State consists of thirty Local Government Areas (LGAs). The major ethnic group in Osun State is Yoruba with sub-ethnic groups such as Ife, Ijesha, Oyo, Ibolo and Igbomina and there are also people from other parts of the country. The people of the State are mostly traders, artisans and farmers. The farmers produce food crops such as yam, maize, cassava, beans and cocoyam. The cash crops produced in the State include: cocoa, kola nut and palm produce. Osun ranks the second largest cocoa producing State in the Southwest after Ondo State (Taphee et al., 2015).The State is also rich in mineral resources such as gold, clay, limestone and granites.

Primary data were used for this study which was obtained using a wellstructured questionnaire. Multistage sampling procedure was used in selecting the sample size. In stage one, purposive sampling was used to select five Local Government Areas (LGAs) based on their prominence in cocoa production and marketing in the State: Ife South, Ife North, Ife East, Obokun and Atakunmosa East. They were also recognized as major cocoa producing areas where cocoa farmers and marketers can be found. The second stage of the sampling involved random selection of two communities from each LGA and they were: Garage-Olode (a.k.a Awolowo town) and Mefoworade in Ife South; Edunabon and Moro in Ife North; Afeki and Iyanfoworogi in Ife East; Esa-Odo and Ilase in Obokun; Iwara and Igangan in Atakunmosa East. Stage three involved random selection of twelve respondents from each of these communities, making a total of one hundred and twenty (120) cocoa marketers. However, one hundred and twenty (120) copies of the questionnaire were administered but one hundred and seventeen (117) were properly filled and returned.

The data were analysed using descriptive statistics, budgetary analysis and SURE. The budgetary analysis was used to determine the cost and returns from cocoa marketing in the study area. The tool was used to determine the overall gross margin and the Net Market Income (NMI). The Gross Margin and Net Market Income will be estimated using equations 1 and 2:

$$
\begin{aligned}
& \sum_{i=1, \ldots, n}^{n} G M_{i}=\mathrm{TVM}_{i}-\mathrm{TVC}_{i} \\
& \sum_{i=1, \ldots, \mathrm{n}}^{n} N M I_{i}=\mathrm{GM}_{i}-\mathrm{TFC}_{i}
\end{aligned}
$$

Where:

$\mathrm{GM}=$ Gross Margin

TVM = Total Value of Market (

TVC $=$ Total Variable Cost $(\#)$

NMI = Net Market Income (

TFC $=$ Total Fixed Cost $(\#)$

$i=1,2,3, \ldots \ldots, \mathrm{n}$

$\mathrm{n} \quad=$ number of marketers sampled for the study

If $\mathrm{GM}>0$, then cocoa marketing is considered profitable.

Furthermore, marketing efficiency (ME) of cocoa marketers was evaluated by dividing value added by marketing by total marketing cost multiply by 100 as specified by Olukosi and Isitor (2004) and Farayola et al. (2013).

$$
M E=\frac{\text { value added by marketing }}{\text { total marketing } \cos t} \times 100 \text { or } \quad M E=\frac{\text { profit }}{\text { total market } \cos t} \times 100
$$


Again, the seemingly unrelated regression equation (SURE) of the linear generalized least squares (GLS) system equations approach (Green, 2000) was employed to perform determinants of cocoa marketing performance in the study area. The equation modelled gross margin, profit, benefit cost ratio, market efficiency and total revenue for comparative purpose using socioeconomic characteristics, marketing characteristics and other factors as the independent variable. The equations for marketing performance (gross margin, profit, returns on investment, marketing efficiency and total revenue) were estimated simultaneously using Seemingly Unrelated Regression with homogeneity and symmetry restrictions imposed.

According to Shalabh (1998), Green (2000) and Gujarati and Potter (2009), the basic philosophy of the SURE model is as follows. The jointness of the equations is explained by the structure of the SURE model and the covariance matrix of the associated disturbances. Such jointness introduces additional information which is over and above the information available when the individual equations are considered separately. So it is desired to consider all the separate relationships collectively to draw the statistical inferences about the model parameters.

Implicitly, the equation was expressed as:

$\mathrm{y}^{*}=\mathrm{f}\left(\mathrm{X}_{1}, \mathrm{X}_{2}, \mathrm{X}_{3}, \mathrm{X}_{4}, \mathrm{X}_{5}, \ldots, \mathrm{X}_{12}, \mathrm{e}_{\mathrm{i}}\right)$

Therefore, using matrix notation, the system of equations was explicitly expressed as:

$$
\left[\begin{array}{l}
y_{g} \\
y_{p} \\
y_{b} \\
y_{m} \\
y_{t}
\end{array}\right]=\left[\begin{array}{l}
\alpha_{1} \\
\alpha_{2} \\
\alpha_{3} \\
\alpha_{4} \\
\alpha_{5}
\end{array}\right]+\left[\begin{array}{l}
X_{11} \ldots X_{15} \\
X_{21} \ldots X_{25} \\
X_{31} \ldots X_{35} \\
X_{41} \ldots X_{45} \\
X_{51} \ldots X_{55}
\end{array}\right]+\left[\begin{array}{l}
\beta_{1} \\
\beta_{2} \\
\beta_{3} \\
\beta_{4} \\
\beta_{5}
\end{array}\right]+\left[\begin{array}{l}
\varepsilon_{1} \\
\varepsilon_{2} \\
\varepsilon_{3} \\
\varepsilon_{4} \\
\varepsilon_{5}
\end{array}\right]
$$

The equations can be written individually as:

$$
\begin{aligned}
& \mathrm{y}_{\mathrm{g}}=\beta_{0}+\beta_{1} \mathrm{X}_{1}+\beta_{2} \mathrm{X}_{2}+\beta_{3} \mathrm{X}_{3}+\beta_{4} \mathrm{X}_{4}+\beta_{5} X_{5}+\ldots+\beta_{15} X_{15}+\beta_{16} X_{16}+\mathrm{e}_{\mathrm{i}} \\
& \mathrm{y}_{\mathrm{p}}=\beta_{0}+\beta_{1} \mathrm{X}_{1}+\beta_{2} \mathrm{X}_{2}+\beta_{3} \mathrm{X}_{3}+\beta_{4} \mathrm{X}_{4}+\beta_{5} X_{5}+\ldots+\beta_{15} X_{15}+\beta_{16} X_{16}+\mathrm{e}_{\mathrm{i}} \\
& \mathrm{y}_{\mathrm{b}}=\beta_{0}+\beta_{1} \mathrm{X}_{1}+\beta_{2} \mathrm{X}_{2}+\beta_{3} \mathrm{X}_{3}+\beta_{4} \mathrm{X}_{4}+\beta_{5} X_{5}+\ldots+\beta_{15} X_{15}+\beta_{16} X_{16}+\mathrm{e}_{\mathrm{i}} \\
& \mathrm{y}_{\mathrm{m}}=\beta_{0}+\beta_{1} \mathrm{X}_{1}+\beta_{2} \mathrm{X}_{2}+\beta_{3} \mathrm{X}_{3}+\beta_{4} \mathrm{X}_{4}+\beta_{5} X_{5}+\ldots+\beta_{15} X_{15}+\beta_{16} X_{16}+\mathrm{e}_{\mathrm{i}} \\
& \mathrm{y}_{\mathrm{t}}=\beta_{0}+\beta_{1} \mathrm{X}_{1}+\beta_{2} \mathrm{X}_{2}+\beta_{3} \mathrm{X}_{3}+\beta_{4} \mathrm{X}_{4}+\beta_{5} X_{5}+\ldots+\beta_{15} X_{15}+\beta_{16} X_{16}+\mathrm{e}_{\mathrm{i}}
\end{aligned}
$$

where:

$\mathrm{y}^{*}$ is the dependent variables and they are $y_{g}, y_{p}, y_{b}, y_{m}$ and $y_{t}$ for gross margin ( $)$, profit $(\$)$, return on investment (value), marketing efficiency $(\%)$ and total revenue ( $)$ respectively.

$\mathrm{X}_{1}=$ Age of marketers (years)

$\mathrm{X}_{2}=$ level of marketer's education (years)

$\mathrm{X}_{3}=$ Household size (number)

$\mathrm{X}_{4}=$ Marital status (married $=1$ and 0 otherwise)

$\mathrm{X}_{5}=\operatorname{Sex}($ male $=1$ and female $=0)$

$\mathrm{X}_{6}=$ Producer price $(\#)$

$\mathrm{X}_{7}=$ Marketing experience (years)

$\mathrm{X}_{8}=$ Marketers' institution group ( $1=$ Cocoa Exporters and 0 otherwise $)$

$\mathrm{X}_{9}=$ Depreciation cost on fixed input $(\mathbb{N})$

$\mathrm{X}_{10}=$ Access to credit (access $=1$ and 0 otherwise)

$\mathrm{X}_{11}=$ Number of store/warehouses 
$\mathrm{X}_{12}=$ Labour cost $(\AA)$

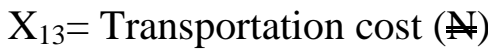

$\mathrm{X}_{14}=$ Season of sales $(1=$ main crop, $0=$ light crop $)$

$\mathrm{X}_{15}=$ Quality of cocoa beans ( $1=$ good quality and 0 otherwise $)$

$\mathrm{X}_{16}=$ Incidence of pilfering/theft $(1=$ yes and $0=$ no $)$

Finally, in order to examine and identify main problems encountered by the cocoa marketers in the study area, descriptive statistics such as frequencies and percentages were used to identify the problems, while four-point likert rating scale (LRS) was used to opine how serious the problems are to the cocoa marketers. Finally, RII was used to determine the problem that needs serious attention should there be any intervention from government, NGOs and stakeholders in cocoa business. RII method is usually used to determine the importance of factor relative to others. It is used to determine the most preferred factor or option based on the response of the respondents.

The four-point scale ranging from 1 (Not at all) to 4 (Very serious) was adopted and transformed to relative importance indices (RII) for each problem or factor or option or effect or solution as the case may be. In case of this study, problem encountered by the cocoa marketers is the factor.

The equation is as follow:

where:

$$
R I I=\frac{\sum W}{A X N}
$$

$W$ is the weighting given to each problem by respondents (1 to 4$) ; A$ is the highest weight (4 in this case); $N$ is the total number of respondents.

Therefore, RII value ranges from 0 to 1 ( 0 not included). The higher the value of RII, the more important the factor (problem) to the respondents in the study area.

\section{RESULTS AND DISCUSSION}

This section explains the summary of data analysis and interpretation of findings in terms of costs and returns associated with cocoa marketing, factors affecting cocoa marketers' performance in the area and main constraints to cocoa marketing in the study area.

\section{Costs and returns associated with cocoa marketing in the study area}

In estimating how buoyant a business is, total cost incurred in the production of a commodity (which comprises costs incurred from fixed items and variable items) and the total receipt (which is the unit price multiply by quantity sold) needs to be carefully examined.

\section{Returns from cocoa market sales}

According to Table 1, it was revealed that many (39.3\%) of the marketers earned between $\$ 1$ and $\$ 2$ million naira per season, while about $29.9 \%$ of the marketers earned less than $\$ 1$ million per season. Nearly $23.9 \%$ of the marketers earned between $\$ 2$ and $\$ 8$ million per season. It was attested that $6.8 \%$ of the sampled cocoa marketers earned at least 8 million naira per season in the study area. The income accrued by the marketers in the area ranges from $\$ 200,000.00$ to $\$ 90,000,000.00$ with mean and standard deviation of $\$ 4,013,677.18$ and 10,709,721.16 respectively. The result implies that the variates were widespread from the mean value and therefore, the income is not normally distributed in the data set. 
Table 1.Distribution of respondents by marketers' income

\begin{tabular}{|c|c|c|}
\hline Total Revenue ( & Frequency & Percent \\
\hline$\leq 1,000,000$ & 35 & 29.9 \\
\hline $1,000,001-2,000,000$ & 46 & 39.3 \\
\hline $2,000,001-4,000,000$ & 17 & 14.5 \\
\hline $4,000,001-6,000,000$ & 7 & 6.0 \\
\hline $6,000,001-8,000,000$ & 4 & 3.4 \\
\hline$>8,000,000$ & 8 & 6.8 \\
\hline Total & 117 & 100.0 \\
\hline
\end{tabular}

Mean $=\$ 4,013,677.18 ;$ Standard deviation $=10,709,721.16 ;$ Minimum $=\$ 200,000.00$; maximum $=\$ 90,000,000.00$

Source: Field Survey, 2017

The total receipt accrued from cocoa marketing is a reflection of how viable the enterprise is. Going by the revenue of the respondents, it can be deduced that the business is yielding substantial proceeds capable of sustaining livelihood in the area.

\section{Measures of profitability of cocoa marketing in the area}

The budgetary analysis comprises total revenue and total cost of marketing. The total cost of marketing comprises total variable cost and total fixed cost. According to Fatuase, Oparinde and Aborisade (2015), budgetary analysis is a germane exercise in production and marketing process in order to assess and determine the financial capability and marketing performance of the enterprise.

It was shown in Table 2 that the total variable cost formed about $51.73 \%$ of the total cost of marketing, while the total fixed cost contributed $48.27 \%$ of the total cost of marketing. Transportation cost accounted for about $23.10 \%$ of the total cost of marketing followed by $21.11 \%$ of cost of maintenance on fueling, repair of engines and office stationeries. The costs of storage $(1.93 \%)$, cost of grading $(2.38 \%)$ and cost of labour $(3.21 \%)$ also formed the total cost of marketing. In addition to this, depreciation costs on weighing scale and aquaboy accounted for nearly $14.12 \%$ and $24.42 \%$ respectively of the total cost. Other depreciation costs on warehouse, tarpaulin, jute bags, ropes, needles, pallets, cutting knives, baskets, counter scale, scoop, rakes, spade and shovel accounted for $9.72 \%$ of the total cost of marketing in the area.

The results of the cost of marketing were similar to the findings of AdaOkungbowa, Ogborodi and Omofonmwan (2013), and Fatuase, Oparinde and Aborisade (2015) who reported that variable costs always take more than $50 \%$ of the cost of marketing of most agricultural enterprises. In contrast to this finding, Emokaro and Ugbekile (2014) reported about $57.7 \%$ of variable cost and $42.3 \%$ of fixed cost, while labour cost $(32.4 \%)$ formed the highest cost in their study carried out in Edo State, Nigeria. Therefore, given the values of gross margin and profit to be $\$ 2,484,968.12$ and $\$ 1,058,658.51$ respectively indicated that cocoa marketing business is a profitable business in the study area.

Again, the value of Return on Investment (ROI) of 1.36 implies that cocoa marketer will realize $\$ 1.36$ on each naira expended. Again, percentage profit of over $35 \%$ further confirmed that cocoa marketing is a highly profitable venture in the study area. Ceteris paribus, marketers should be able to pay back loans even at commercial bank interest rate of at least $18 \%$ per annum. The value of Expense Structure Ratio (ESR) of 0.93 indicated that the variable cost incurred in the business is greater than money expended on fixed cost by $7 \%$, while gross ratio (0.74) also revealed that total 
revenue accrued from cocoa marketing is greater than total cost expended in the course of the business by $26 \%$. All these profitability measures confirmed and reiterated the profitability of cocoa marketing in the area.

The results of this study were similar to the findings of Adebo, Ayodele and Olowokere (2015) who found out a positive gross margin with a ROI of 1.57 in their study carried out among small-scale oil palm marketers in Ekiti State, Nigeria. In the same vein, this result concurs with the findings of Gotsch and Burger (2001), Folayan et al. (2006) and Taphee et al. (2015). They all reported that market performance analysis revealed that cocoa marketing is profitable.

Folayan et al. (2007) opined that positive and size of profit obtained for each cocoa marketing institution is an indication that these institutions were able to recover their operating expenses; hence post-deregulation cocoa marketing era is profitable and efficient in their studies carried out in Nigeria. In addition to this, Oseni and Adams (2013) observed and reported similar results in both conventional cocoa production and certified cocoa production in their studies carried out in Ondo State, Nigeria, all the profitability indices (NPV, BCR, IRR and the GM) indicated that cocoa business is profitable.

Table 2.Results of profitability measures of cocoa marketing in the area

\begin{tabular}{lrr}
\hline Items & Mean (N) & Percentage \\
\hline & Fixed Input & \\
Depreciation cost on Weighing scale & $417,360.98$ & 14.12 \\
Depreciation cost on Aquaboy & $721,517.65$ & 24.42 \\
Depreciation cost on warehouse & $89,054.55$ & 3.01 \\
Depreciation cost on tarpaulin & $72,378.94$ & 2.45 \\
Depreciation cost on pallets & $6,636.36$ & 0.22 \\
Depreciation cost on jute bags, ropes and needles & $63,110.68$ & 2.14 \\
Depreciation cost on cutting knives and baskets & $12,233.34$ & 0.41 \\
Depreciation cost on counter balance & $27,435.00$ & 0.93 \\
Depreciation cost on scoop & $4,640.00$ & 0.16 \\
Depreciation cost on rakes, spade & $11,942.11$ & 0.40 \\
\hline Total Fixed Cost (TFC) & $\mathbf{1 , 4 2 6 , 3 0 9 . 6 1}$ & $\mathbf{4 8 . 2 7}$ \\
\hline & & \\
Cost of labour & $94,840.70$ & 3.21 \\
Transportation & $682,705.68$ & 23.10 \\
Cost of storage & $56,892.14$ & 1.93 \\
Grading fees & $70,473.91$ & 2.38 \\
Cost of maintenance & $623,796.63$ & 21.11 \\
\hline Total Variable cost (TVC) & $\mathbf{1 , 5 2 8 , 7 0 9 . 0 6}$ & $\mathbf{5 1 . 7 3}$ \\
\hline Total Cost of Marketing (TCM) = TFC + TVC & $2,955,018.67$ & 100.00 \\
Total Revenue (TR) & $4,013,677.18$ & \\
Gross margin = TR - TVC & $2,484,968.12$ & \\
Profit = TR - TCM & $1,058,658.51$ & \\
\% profit or ME = (profit/TCM)*100 & 35.83 & \\
ROI = TR/TCM & & \\
ESR = TFC/TVC & & \\
Gross ratio = TCM/TR & 0.93 & \\
\hline SourCe: Field Survey, 20077.36 & \\
\hline
\end{tabular}

Source: Field Survey, 2017. 
It was also observed from the results that more profits can still be made if the marketers could reduce expenses on labour, transportation and maintenance by embracing modern technologies that increase efficiency and thereby the productivity in the business.

\section{Determinants of cocoa marketing performance in the study area}

The results of the Seemingly Unrelated Regression Equation (SURE) in determining marketing performance were presented in Table 3. The chi-square statistic ranges from 16.00 to 22.24 and they are all significant at $1 \%$ level. This implies that the null hypothesis of the restrictions of valid homogeneity and symmetry for the system equations were accepted. The R-squared of the estimated gross margin, profit, Return on Investment, market efficiency and total revenue equations were $0.735,0.834,0.727$, 0.725 and 0.911 respectively with the total sales equation having the highest R-squared value. This implies that $73.5 \%, 83.4 \%, 72.7 \%, 72.5 \%$ and $91.1 \%$ of the variability in cocoa marketer's performance (gross margin, profit, Return on Investment, market efficiency and total revenue respectively) were explained by the sixteen (16) explanatory variables included in the model.

Generally, the coefficients of variables that were positive with the regressands (i.e. gross margin, profit, Return on Investment, market efficiency and total revenue) imply that increase in the value of any of these variables will increase and have upward relationship with the dependent variable and vice-versa.

According to Table 3, the coefficients of age and marital status of the marketers were all positive with the regressands except total revenue which had negative coefficient. The result further showed that the coefficient of age and marital status were statistically significant in affecting gross margin and profit respectively at 5\% levels apiece. This implies that older and married cocoa marketers increase gross margin and profit by $\$ 948.95$ and $\$ 128,123.40$ respectively, but their total revenue may be reduced. Except in total revenue, this study agrees with Anyoha (2010) and Farayola et al. (2013) who viewed that older farmers are more experienced and efficient in taking decisions regarding agricultural production and marketing.

The coefficient of household size was positive and statistically significant $(\mathrm{P}<$ $0.05)$ with all the dependent variables. The results showed that a unit increase in the number of family size will increase gross margin, profit and total revenue by $\$ 45,989.48, \$ 51,993.12$ and $\$ 282,044.00$ respectively in the area. Added to this, for every naira expended on cocoa marketing as a result of family size will yield $\$ 1.91$ with an increased market efficiency of $29.11 \%$. According to Farayola et al. (2013), the household members may help in providing some marketing functions at a reduced cost which is an incentive to an efficient marketing system. The result is in agreement with that of Quartey (2005) who stated that household size affects efficiency since there may be synergies from larger household size in both production and consumption.

The coefficient of year of education was also positive and statistically significant at most 5\% level with all the dependent variables. This implies that increase in year spent in school will cause a positive increase in the value of gross margin, profit and total revenue by $\$ 66,761.06, \$ 22,304.78$ and $\$ 164,992.70$ respectively in the area. In the same vein, as the marketers' year of education increases, $62 \mathrm{kobo}$ will be gained on every naira expended on cocoa marketing business with an increased market efficiency of $56.12 \%$ in the area. The result supports Idowu et al. (2007) who found out positive and significant relationship with total revenue in examining the effect of market deregulation on cocoa production in Southwest, Nigeria.

The coefficient of year of cocoa marketing experience was statistically 
significant $(\mathrm{P}<0.05)$ and positive with the dependent variables. This indicated that more experienced cocoa marketers increases gross margin, profit and total revenue by $\$ 67,670.49, \$ 1,126.20$ and $\$ 66,189.75$ respectively. Furthermore, increase in year of experience will contribute 56kobo to every naira expended on cocoa marketing business with market efficiency of $16.17 \%$ in the area.

Marketer's category showed a positive and significant association with the dependent variables. It was observed that exporters made positive contributions of $\$ 152,023.10, \$ 1,121.89$ and $\$ 978,631.77$ to the gross margin, profit and total revenue respectively, relative to other marketers' groups. The ROI and market efficiency values revealed that for every naira expended by the exporters, 8.87 was gained from the cocoa marketing business with the efficiency of $23.89 \%$ in the area.

The depreciation cost on fixed inputs had a negative coefficient with all the dependent variables but statistically significant $(\mathrm{P}<0.05)$ for profit, $\mathrm{ROI}$ and market efficiency. This is an indication that a naira increase in the value of fixed inputs will reduce profit by $\$ 376.97$. Moreover, the value of fixed inputs will reduce profit by $68 \mathrm{k}$ for every naira expended in the cocoa marketing enterprise with a reduced market efficiency of $0.88 \%$ in the area.

Number of stores had a positive coefficient with all the dependent variables but statistically significant at $5 \%$ level with total revenue. This implies that a unit increase in the number of stores will increase total revenue by $\$ 6,658.98$ in the area.

Cost of labour had negative coefficients but was statistically significant at most $5 \%$ level. It means that increase in the cost of labour will reduce gross margin, profit and total revenue by $\$ 93.79, \$ 37,697.39$ and $\$ 937.91$ respectively. Again, for every naira expended on cocoa marketing business as a result of labour cost, reduce the gain accrued by $87 \mathrm{k}$ with a reduced market efficiency of $2.21 \%$. This is in contrast to the research findings by Taphee et al. (2015) who reported that the coefficient of labour was found to be positive and significant at $1 \%$ level, implying that as labour cost increases, so also the profit.

Cost of transportation's coefficient was negative but statistically significant with all the dependent variables. This implies that a naira increase in the cost of transportation will decrease gross margin, profit and total revenue by $\$ 39,819.88$, $\$ 54,112.90$ and $\$ 2,459.65$ respectively. At the same time, for every naira spent as a result of transportation, will reduce gain accrued by $\$ 1.10$ with a reduced market efficiency of $13.22 \%$ in the area.

Season of sales had positive coefficients and they are statistically significant in addressing gross margin, ROI and total revenue. It was revealed that main season of sales increases gross margin and total revenue by $\$ 21,081.01$ and $\$ 19,723.93$ respectively, and for every naira expended during the main season, a gain of $77 \mathrm{kobo}$ was accrued by the marketers in the area.

The cocoa bean quality had a positive coefficient with all the dependent variables but statistically significant with total revenue. This implies that quality of cocoa bean increases the total revenue by $\$ 345.23$ in the area.

The incidence of theft/pilfering had negative coefficient with all the dependent variables but statistically significant with gross margin and total revenue. This is an indication that the incidence of pilfering will reduce the values of gross margin and total revenue by $\$ 12.45$ and $\$ 9,345.23$ respectively in the area. Therefore, Akinfolarin et al. (2012) examined the operational activities of cocoa export processing factories in Ondo State, Nigeria and found out that cocoa export processing factories are operating at a loss partly due to the highly capital intensive nature of cocoa processing. 
Table 3. Determinants of marketing performance using Seemingly Unrelated Regression Equation (SURE)

\begin{tabular}{|c|c|c|c|c|c|}
\hline Variables & Gross margin & Profit & ROI & ME & TR \\
\hline Age & $\begin{array}{r}948.95^{*} \\
(1.98)\end{array}$ & $\begin{array}{r}2729.32 \\
(1.45)\end{array}$ & $\begin{array}{r}0.14 \\
(1.78)\end{array}$ & $\begin{array}{l}13.97 \\
(0.99)\end{array}$ & $\begin{array}{r}-5634.09 \\
(1.29)\end{array}$ \\
\hline Sex & $\begin{array}{r}23389.03 \\
(1.71)\end{array}$ & $\begin{array}{r}30484.64 \\
(1.87)\end{array}$ & $\begin{array}{r}9.60 \\
(0.87)\end{array}$ & $\begin{array}{r}19.60 \\
(1.09)\end{array}$ & $\begin{array}{r}53422.57 \\
(1.00)\end{array}$ \\
\hline Marital status & $\begin{array}{r}7677.36 \\
(1.01)\end{array}$ & $\begin{array}{r}128123.40^{*} \\
(2.12)\end{array}$ & $\begin{array}{r}0.94 \\
(1.02)\end{array}$ & $\begin{array}{r}1.61 \\
(1.39)\end{array}$ & $\begin{array}{r}-1256.88 \\
(0.99)\end{array}$ \\
\hline Household size & $\begin{array}{r}45989.48^{*} \\
(2.01)\end{array}$ & $\begin{array}{r}51993.12^{*} \\
(2.22)\end{array}$ & $\begin{array}{l}2.91 * \\
(2.11)\end{array}$ & $\begin{array}{r}29.11 * \\
(2.05)\end{array}$ & $\begin{array}{r}282044.10^{* * *} \\
(3.78)\end{array}$ \\
\hline Education & $\begin{array}{r}66761.06 * * \\
(4.09)\end{array}$ & $\begin{array}{r}22304.78 * * \\
(2.49)\end{array}$ & $\begin{array}{l}1.62 * \\
(2.08)\end{array}$ & $\begin{array}{r}56.12 * \\
(2.01)\end{array}$ & $\begin{array}{r}164992.70 * * \\
(3.97)\end{array}$ \\
\hline Experience & $\begin{array}{r}67670.49 * * \\
(5.12)\end{array}$ & $\begin{array}{r}1126.20 * * \\
(7.01)\end{array}$ & $\begin{array}{l}1.56^{*} \\
(2.02)\end{array}$ & $\begin{array}{r}16.17 * \\
(2.09)\end{array}$ & $\begin{array}{r}66189.75^{* *} \\
(4.01)\end{array}$ \\
\hline Producer price & $\begin{array}{r}542.17 \\
(1.23)\end{array}$ & $\begin{array}{r}212.76 \\
(1.39)\end{array}$ & $\begin{array}{r}0.06 \\
(0.09)\end{array}$ & $\begin{array}{r}1.02 \\
(0.34)\end{array}$ & $\begin{array}{r}367.98 \\
(1.56)\end{array}$ \\
\hline MIG (exporter) & $\begin{array}{r}152023.10^{* *} \\
(2.45)\end{array}$ & $\begin{array}{r}1121.89^{*} \\
(2.27)\end{array}$ & $\begin{array}{l}9.87 * \\
(2.33)\end{array}$ & $\begin{array}{r}23.89 * \\
(2.23)\end{array}$ & $\begin{array}{r}978631.77 * * \\
(4.56)\end{array}$ \\
\hline $\begin{array}{l}\text { Cost of fixed } \\
\text { input }\end{array}$ & $\begin{array}{r}-24.59 \\
(1.80)\end{array}$ & $\begin{array}{r}-376.97 * \\
(2.10)\end{array}$ & $\begin{array}{r}-1.68^{*} \\
(2.02)\end{array}$ & $\begin{array}{l}-0.88^{*} \\
(2.00)\end{array}$ & $\begin{array}{r}-24596.11 \\
(1.19)\end{array}$ \\
\hline Credit & $\begin{array}{r}40546.34 \\
(1.36)\end{array}$ & $\begin{array}{r}38354.41 \\
(1.00)\end{array}$ & $\begin{array}{r}1.01 \\
(1.01)\end{array}$ & $\begin{array}{r}0.76 \\
(1.23)\end{array}$ & $\begin{array}{r}405463.40 \\
(0.98)\end{array}$ \\
\hline $\begin{array}{l}\text { Number of } \\
\text { stores }\end{array}$ & $\begin{array}{r}4712.98 \\
(1.77)\end{array}$ & $\begin{array}{r}234.43 \\
(1.37)\end{array}$ & $\begin{array}{r}0.81 \\
(1.56)\end{array}$ & $\begin{array}{r}0.43 \\
(0.99)\end{array}$ & $\begin{array}{r}6658.98 * \\
(1.99)\end{array}$ \\
\hline Labour cost & $\begin{array}{r}-93.79 * * \\
(3.12)\end{array}$ & $\begin{array}{r}-37697.39^{*} \\
(2.11)\end{array}$ & $\begin{array}{r}-1.87 * \\
(2.21)\end{array}$ & $\begin{array}{r}-2.22 * \\
(1.99)\end{array}$ & $\begin{array}{r}-937.91 * \\
(2.00)\end{array}$ \\
\hline $\begin{array}{l}\text { Transportation } \\
\text { cost }\end{array}$ & $\begin{array}{r}-39819.88^{*} \\
(1.99)\end{array}$ & $\begin{array}{r}-54112.90^{*} \\
(2.30)\end{array}$ & $\begin{array}{r}-2.10 * * \\
(4.71)\end{array}$ & $\begin{array}{r}-13.22^{*} \\
(2.01)\end{array}$ & $\begin{array}{r}-2459.65 * * \\
(3.67)\end{array}$ \\
\hline Season of sales & $\begin{array}{r}21080.01^{*} \\
(2.09)\end{array}$ & $\begin{array}{r}893.87 \\
(1.02)\end{array}$ & $\begin{array}{r}0.77 * * \\
(2.89)\end{array}$ & $\begin{array}{r}0.02 \\
(1.79)\end{array}$ & $\begin{array}{r}19723.93^{* *} \\
(3.54)\end{array}$ \\
\hline Cocoa quality & $\begin{array}{r}234.87 \\
(1.11)\end{array}$ & $\begin{array}{r}123.56 \\
(1.55)\end{array}$ & $\begin{array}{r}1.10 \\
(1.76)\end{array}$ & $\begin{array}{r}0.71 \\
(0.99)\end{array}$ & $\begin{array}{r}345.32 * * \\
(2.50)\end{array}$ \\
\hline $\begin{array}{l}\text { Incidence of } \\
\text { theft }\end{array}$ & $-912.45^{*}(2.00)$ & $\begin{array}{r}-3343.45 \\
(1.21)\end{array}$ & $\begin{array}{r}-0.88 \\
(1.63)\end{array}$ & $\begin{array}{r}-0.07 \\
(1.24)\end{array}$ & $\begin{array}{r}-9345.23 * \\
(2.10)\end{array}$ \\
\hline Constant & $\begin{array}{r}39072.19 \\
(1.31)\end{array}$ & $\begin{array}{r}18566.26 \\
(2.15)\end{array}$ & $\begin{array}{l}31.67 \\
(1.33)\end{array}$ & $\begin{array}{l}30.67 \\
(2.06)\end{array}$ & $\begin{array}{r}184814.50 \\
(1.81)\end{array}$ \\
\hline $\mathrm{R}^{2}$ & 0.735 & 0.834 & 0.727 & 0.725 & 0.911 \\
\hline $\mathrm{Chi}^{2}$ & $17.76^{* *}$ & $17.85 * *$ & $17.76^{* *}$ & $17.74 * *$ & $22.24 * *$ \\
\hline
\end{tabular}

*** means significant at 5\% and $1 \%$ levels respectively. ROI $=$ Return on Investment; ME $(\%$ profit $)=$ Market efficiency; TR $=$ Total revenue; Figures in parentheses are the calculated $\mathrm{t}-$ values, $\mathrm{MIG}=$ marketer's institution group

Source: Field Survey, 2017 
The results ascertained that different factors are responsible for the behaviour of market performance in the area. It was noted that some variables significantly influenced all the parameters of cocoa performance and this needs to be carefully addressed for policy recommendations. The costs of labour and transportation had a negative relationship with all the performance's parameters and this reiterated the findings from costs and returns analysis.

\section{Constraints militating against cocoa marketers in the study area}

The responses on the main problems encountered by the marketers were structured from "Not at all" to "Very serious" with a weight scale of 1 to 4 respectively. The statement with highest percentage of the responses in each of the statement items were used as the general opinion of the respondents and Relative Importance Index (RII) was used to determine the most serious problem that need urgent attention in the study area.

According to Table 4, inadequate capital to invest in cocoa marketing business has been observed as a serious problem in the study area where $43 \%$ of the respondents formed the majority that agreed with the statement. The value of RII (0.73) ranked it to be the fifth most serious problem that needs urgent attention in the study area. Observations from the field survey revealed that some of the players could still expand their market volume if there are adequate and available funds. It was also reported that some have backed out as a result of inadequate capital for the business.

This result shared the view of Jaeger (1999) who stated that turbulent trading conditions have deterred a number of players entering the market, and the export and purchase are usually left to specialists. Again, it was shown that about 53.6\% of the respondents saw environmental hazards such as extreme weather behaviours and pests and diseases infestation as a serious problem in the area. The value of RII (0.65) ranked it as eighth problem that needs attention.

Rainfall has been identified as the main environmental factor that affect cocoa marketing and this happens during the light season of sales. Despite the problem of rainfall, most of the rich marketers had artificial dryers but they still prefer natural dryers (sunshine) due to cost implications.

Government policies most especially taxation and grading fees have been ranked fourth given the RII value of 0.80 . It was also revealed that many (50\%) of the sampled respondents saw it as a very serious problem. The respondents complained on how government increases their tax and made it unpleasant to most of the marketers.

Poor road network most especially the feeder roads that lead to the producers is nothing to be written home about. This problem was ranked first given the RII value of 0.89 with nearly $57 \%$ of the respondents viewed it as a very serious problem that needs urgent attention in the area. They complained that they find it hard to purchase cocoa beans from the producers due to bad roads that lead to the producer's farms. This has also caused damages to the cocoa beans thereby reducing its quality.

What majority of the marketers do in this case was to use motor cycle (bike or "okada") transportation which is limited in terms of its carrying capacity to the nearest motorable road where vehicle can be used. High cost of transportation was noticed to be the second most serious problem given the value of RII to be 0.86 . This problem was linked to bad roads and hike in fuel prices over the years. They also complained that this has also increased the cost of maintaining their mode of transportation such as bike and 
vehicle. Incidence of theft and pilfering was mild in the study area as about $40.6 \%$ of the respondents formed the majority that attested to the problem.

The value of RII (0.58) ranked it to be the least (ninth) in the area that needs urgent attention. The marketers stated that theft was only rampant whenever there is an increase in price and during the peak season. In effect, majority of them hired security men (night guard) to curb the act in the area during the peak seasons.

About $51.8 \%$ of the respondents attested that inadequate information about cocoa marketing most especially price movement in the global market and the likely effect on the marketers has been a serious problem in the area. This was ranked as seventh problem that needs attention in the study area given the value of RII as 0.67. Lack of trust was seen as a serious problem and about $55.2 \%$ of the respondents attested to it.

This was ranked as sixth problem that need attention by the marketers given RII of 0.69. Majority of the marketers complained that most of the producers do fail to sell their products to them despite the assistance the marketers have rendered such as agrochemicals and loan in exchange of cocoa beans.

Cocoa price fluctuation/instability was ranked to be the third problem that needs urgent attention in the study area, given the value of RII to be 0.81 . Majority $(64.2 \%)$ of the sampled respondents observed it as a very serious problem that needs to be attended to urgently. Since the price is unpredictable, the marketers find it hard to buy in stock most especially during the light season. This study shared the view of Jaeger (1999) who opined that the price of cocoa responds to a number of influences including the availability of beans at present and as expected in the future, as well as more technical issues of the analysis of price movements. It is particularly sensitive to sentiment among the major players and detailed analysis of supply and demand only covers part of the story.

The research findings concur with the view of Daniel (2009) who stated that fluctuations in market price, lack of market information as well as spoilage and low quality products, which reduce market prices, are critical constraints that adversely affect the upstream activities in cocoa marketing and processing. Again, the results of this study were similar to the findings of Farayola et al. (2013) that was carried out among small-holder cocoa marketers in Oyo State, Nigeria. They found out that pests and diseases, inadequate storage facilities, price instability, high cost of transportation, poor infrastructure, high taxation cost, high cost of preservation and low access to finance are the main constraints to cocoa marketing in the study area.

In addition, Anyanwu et al. (2003), stated that cocoa are perishable produce and the farmers may not have the technology to process and preserve them, the entire products are offered for marketing immediately, price are forced down and the farmers may not be adequately rewarded for their labour. Again, Akinfolarin et al. (2012) examined the operational activities of cocoa export processing factories in Ondo State, Nigeria and revealed that cocoa processing companies are confronted with a variety of challenges ranging from high cost of production including that of unpredictable and fluctuating prices of raw cocoa beans, inevitably high and additional cost of generators and diesel resulting from epileptic power supply to lack of funds when needed. 
Table 4.Distribution of respondents according to problems in cocoa Marketing ( $\mathrm{n}=117)$

\begin{tabular}{lccrrrr}
\hline Constraints & $\begin{array}{c}\text { Very } \\
\text { serious }(\boldsymbol{\%})\end{array}$ & $\begin{array}{c}\text { Serious } \\
\mathbf{( \% )}\end{array}$ & $\begin{array}{c}\text { Mild } \\
(\mathbf{\%})\end{array}$ & $\begin{array}{c}\text { Not at all } \\
(\mathbf{\%})\end{array}$ & RII & Rank \\
\hline Poor road network & 66.7 & 33.3 & - & - & 0.89 & $1^{\text {st }}$ \\
High cost of & 57.0 & 39.5 & 3.5 & - & 0.86 & $2^{\text {nd }}$ \\
transportation & & & & & & \\
Price fluctuations & 64.2 & 32.1 & - & 3.8 & 0.81 & $3^{\text {rd }}$ \\
High grading fees & 50.0 & 31.6 & 14.9 & 3.5 & 0.80 & $4^{\text {th }}$ \\
Inadequate capital & 35.5 & 42.7 & 19.1 & 2.7 & 0.73 & $5^{\text {th }}$ \\
Lack of trust & 27.6 & 55.2 & 13.3 & 3.8 & 0.69 & $6^{\text {th }}$ \\
Incidence of theft & 19.1 & 51.8 & 22.7 & 6.4 & 0.67 & $7^{\text {th }}$ \\
Environmental hazards & 13.6 & 53.6 & 30.0 & 2.7 & 0.65 & $8^{\text {th }}$ \\
Inadequate information & 15.8 & 39.6 & 40.6 & 4.0 & 0.58 & $9^{\text {th }}$ \\
\hline Note: RII
\end{tabular}

Note: RII means Relative Importance Index

Source: Field Survey, 2017

The above results affirmed that cocoa marketers are facing several challenges that are negatively affecting the performance of cocoa marketing in the area. All the stated problems threaten the sustainability of the cocoa marketing business in the area and it will continue to deteriorate if not given adequate attention for a decisive solution.

\section{CONCLUSION AND RECOMMENDATIONS}

This section draws out conclusion and recommendations based on the findings of this study.

\section{Conclusion}

Based on the findings of this study, it was concluded that cocoa marketing enterprise is a highly profitable enterprise. It is an enterprise that accrues much income and profit that could sustain family standard of living if properly and effectively managed. Despite the challenges faced by the marketers such as poor road networks, hike cost of transportation and price fluctuation, marketers were still able to pay back loans even at commercial bank interest rate of at least two digits per annum. Mostly, the variable cost incurred in the business is relatively greater than the money expended on fixed cost which also means that total revenue accrued from cocoa marketing is greater than total cost expended in the course of the business. It was also concluded that some of the socio-economic factors and inputs used determined the performance of the cocoa marketers.

\section{Recommendations}

The following policy recommendations were proffered based on the findings of this study: Government should construct roads most especially the feeder roads that lead to the producers to reduce the problem of high transportation cost. This will help the marketers to have easy access to the producers in the most interior part of the rural areas. The cost of fuel should be drastically reduced by the government. This has a significant effect on the performance of the cocoa marketers in the area. Government charges most especially grading fees on cocoa marketers should be reviewed. It should be reduced in order to encourage people of low income to venture into the business. 
Government should also help in stabilizing cocoa prices and give credit to the marketers in order to boost their sales. This can be achieved through the Bank of Agricultural (BOA) and the Bank of Industry (BOI). The interest rate should not be more than a digit so that the more marketers would be encouraged and the bureaucratic bottle-neck of accessing funds should be reduced so as to encourage the marketers to access the funds.

\section{REFERENCES}

Ada-Okungbowa, C.I., Oghorodi, O., Omofonmwan, E.I. (2013).Profitability of palm oil marketing in Ethiope East Local Government Area of Delta State, Nigeria. Journal of Applied Science and Agriculture, 8(4): 342-345.

Adebo. G.M., Ayodele, O.J., Olowokere. K. (2015). Palm Oil Production as a Poverty Alleviation Strategy among Small-scale Farmers in Ekiti State, Nigeria. World Journal of Agricultural Research, 3(2): 43-48.

Ajetomobi, J.O. (2014).Post-Liberalization Markets, Export Firm Concentration, and Price Transmission along Nigerian Cocoa Supply Chains. AGRODEP Working Paper 0005.IFPRI's Publications. Pp. 8-10.

Akinfolarin, A.O., Oseni, J.O. and Imoudu, P.B. (2012).Operational Activities of Cocoa Export Processing Factories in Ondo State, Nigeria. Journal of Agricultural Science, Vol. 3(1): 5-8.

Anyanwu, B.O. (2003). Agricultural Science for Schools and Colleges. Africa First Publishers, Onitsha, Nigeria.pp100-104.

Anyoha, N. O. (2010). Effects of Environmental Degradation on Agriculture in Delta Central Agricultural Zone, Delta State. International Journal of Agriculture and Rural Development (IJARD).13(1): 54- 60.

Daniel. S. U. (2009). Problems and Prospects of Commercial Small and Medium Scale Cocoa and Oil palm Production in Cross River State, Nigeria. Journals of Applied Sciences Research, 5(7): 827-832.

Emokaro, C. O. and Ugbekile, P. C. (2014). Economic Analysis of Oil Palm Processing in Ovia North East and Ikpoba-Okha Local Government Areas of Edo State, Nigeria. Nigerian Journal of Agriculture, Food and Environment. 10(2):70-78.

Fadipe, A.E.A., Adenuga, A.H. and Ilori, T.E. (2012). Economic Analysis of Cocoa Production in Oyo State, Nigeria. Nigerian Journal of Agriculture, Food and Environment, 8(4):58-63.

Fatuase, A.I., Oparinde, L.O. and Aborisade, A.S. (2015). Performane and Resouse-Use Efficiency among Yam Production in Owo Local Government Area of Ondo State, Nigeria. Applied Tropical Agriculture, 20(1): 83 - 88.

Farayola, C. O., Akintaro, O. S., Yahaya, A. A., and Oni, O.O. (2013). Determinants of Marketing Efficiency among Small-Holder Cocoa Marketers in Oyo State, Nigeria. International Journal of Management and Social Sciences Research (IJMSSR) Vol. 2, No. 11, $33-43$.

Folayan, J.A., Daramola, G.A. and Oguntade, A.E. (2006).Structure and performance Evaluation of Cocoa Marketing Institutions in South Western Nigeria: An Economic Analysis. Journal of Food, Agriculture and Environmental, Vol.4(2): 
$123-128$

Folayan, J.A., Oguntade, A.E. and Ogundari, K. (2007).Analysis of Profitability and Operational Efficiencies of Cocoa Marketing: Empirical Evidence from Nigeria. Journal of Social Sciences, Vol.15(2): 197-199.

Gotch, N. and Burger, K. (2001).Dynamic Supply response and welfare effects of technological change on perennial crops: The case of cocoa in Malaysia. American Journal of Agricultural Economics, 83 (2): 272-285.

Green, W.H. (2000). Econometric Analysis, $4^{\text {th }}$ ed. Prentice Hall, Upper Saddle River, New Jersey: Prentice-Hall.

Gujarati, D.N. and Porter, D.C. (2009). Basic Econometrics. Fifth Edition, McGrawHILL International Editions Economics Series, Singapore.

ICCO (2016): International Cocoa Organisation (ICCO) Statistics on Smallholders Involved in Cocoa Production, ICCO Global Estimates available at http://www.icco.org/questions/smallholders.htm 20-02-16

Idowu, E. O., Osuntogun, D. A. and Oluwasola, O. (2007). Effects of Market Deregulation on Cocoa (Theobroma cacao) Production in Southwest Nigeria. African Journal of Agricultural Research Vol. 2 (9), pp. 429-434.

Jaeger, S. (1999). Cocoa Markets in Development Countries, What Do We Know? Food Studies Group Working Paper No. 8, Oxford.

National Population Commission (2006). 2006 population and Housing Census of the Federal Republic of Nigeria, Abuja. Vol. 1: 67-76.

Nigeria Export Promotion Council (2001). Why Export Publication of Nigeria Export Promotion Council. Abuja: NEPC.

Nwachukwu, I.N., Ezeh, C.I. and Emerole, C.O. (2012).Competitiveness and Determinants of Cocoa Export from Nigeria. African Crop Science Journal, Vol. 20(2):487-491.

Ogunleye, K.Y and Oladeji, J.O.(2007). Choice of Cocoa Market Channels among Cocoa Farmers in Ila Local Government Area of Osun State, Nigeria. MiddleEast Journal of Scientific Research. Vol. 2(1):14-20.

Oladosu, J.O. and Yekini, W.A. (2008).Communication Effectiveness between Cocoa Research Institute of Nigeria (CRIN) and Cocoa Farmers in Cocoa Producing Areas of Oyo State, Nigeria. Journal of Rural Research and Information, Vol.1(5): 77-86.

Oseni, J.O. and Adams, A.Q. (2013). Cost Benefit Analysis of Certified Cocoa Production in Ondo State, Nigeria. Invited Paper Presented at the 4th International Conference of the African Association of Agricultural Economists, September 22-25, 2013, Hammamet, Tunisia.

Owofemi, D. (2008). Growing a Successful Non-Oil Export Business: A Case Study, A Paper Presented at the International Conference on Non-Oil Export in Nigeria Organized by CIBN/NEXIM Bank.

Quartey, P. (2005). The Impact of Migrant Remittances on Household Welfare in Ghana, a Final Research Report Presented in AERC Biannual Research Workshop pp 16 -24.

Shalabh, I.K. (1998). Econometrics: Seemingly Unrelated Regression Equations Models. 
Taphee, B.G., Musa, Y.H. and Vosanka, I.P. (2015).Economic Efficiency of Cocoa Production in Gashaka Local Government Area, Taraba State, Nigeria. Mediterranean Journal of Social Sciences. Vol 6 (1): 570-572. 